\title{
Great Expectations?: Between Boredom and Sincerity in Jewish Ritual 'Attendance'
}

\author{
Simon Coleman
}

\section{Introduction: a long time coming}

The date is Saturday, 8 May 1976, and I am feeling uncomfortable - stifled in a new suit and tie, standing in a crowded room, at the beginning of one of the hottest English summers on record. But there are other, more urgent reasons for my unease. The room is the main hall of a Reform ${ }^{1}$ Synagogue in North London, and the occasion is my Bar Mitzvah - the ceremony to mark the coming of age of Jewish boys who have reached the age of thirteen, requiring their public reading or chanting in Hebrew of an extract from the Torah. ${ }^{2}$ By declaiming the ancient language, and despite my lack of religious conviction, I am signalling that I am competent to participate in public worship and to accept moral accountability for my actions as a Jew. Not exactly a time to relax.

While I stand on the bimah, ${ }^{3}$ behind me sits the normal Saturday morning congregation of the synagogue, alongside my extended family and friends, who have gathered to witness my performance. Indeed, my memory of that summer, apart from the ferocious heat that turned cricket pitches into concrete deserts plagued by ladybugs, is of spending Saturday morning after Saturday morning sweltering in the same suit while I attended the Bar Mitzvahs of my Jewish friends as, one after the other, we were transformed into ritually responsible adults in synagogues dotted around the city.

At this particular moment, I am nearing the end of my own Bar Mitzvah, and I'm staring up at the rabbi. He congratulates me for all the hard work I have put 
in during the past year, and for making my family and friends proud. But then he finishes with a loaded sign-off, situated rhetorically somewhere between a warning and an exhortation: 'I hope we'll be seeing you here next week as you continue your life as a Jewish adult!' So this is what it is all about, in the end: continuity, reproduction, the active extension of an identity granted at birth. My immediate response is to think back over my preparatory encounters with the synagogue over the past year or more: the reciting of texts in a language whose meaning remained utterly opaque and largely undiscussed; listening to harangues about the importance of Israel in my life; avoiding the eye of the ill-tempered Hebrew teacher who at one point had been stuck in Israel and rendered unable to 'instruct' us for six weeks - an absence long enough to hint at the existence of a merciful deity; but above all, enduring tedious services, often accompanied by my equally secular and sceptical father, as we half-listened to prayer after prayer from the siddur ${ }^{4}$ while keeping an eye on the clock. To me, the sheer repetition of phrases in Hebrew conveyed the sense that services were trapping us within a recursive ritual loop, making time stand still as we waited for the chance to leave.

All of which means that, when the rabbi intones on the bimah that he looks forward to seeing me next week, I think to myself: 'You're not seeing me ever again in this synagogue.' So much for continuity and reproduction.

Time does move on. The date is now 10 September 2010. I am with my wife Leslie, ${ }^{5}$ children and in-laws in another, much larger hall, located in a Jewish community centre in downtown Toronto. Leslie - buoyed by positive childhood experiences of synagogue life in the Los Angeles Valley - is keen to join a Jewish community, given that we have just moved to Canada. I am feeling quite uncomfortable again in anticipation of this particular gathering, which is there to mark Rosh HaShanah, the Jewish New Year. My first surprise when we reach the hall is not just its size but also the fact that it is full - jampacked with smartly dressed parents, children and students, and we struggle to find seats. People continue to mill in and out during most of the service, often chatting with neighbours in a way that seems more relaxed than my memories of English synagogues in the 1970s. But my second surprise is that, while I do not particularly want to be there, the experience is not quite as bad - as boring - as I had expected. I actually find myself looking around and mentally taking notes as I observe various styles of prayer and engagement; conversations happening left, right and centre; people's subtly different styles of handling the texts that they are supposed to read but most of the time just hold, occasionally turning pages to keep up with the service. 
Have I started to convert? No, not at all. Even to this day, I would be perfectly happy never to attend another synagogue service, unless on ethnographic or familial duty. However, I am a different person from that 13 year old. Not only am I now a husband and father, I am also an anthropologist of religion with a professional habitus that can slip into comparative, fieldwork mode. In this regard, I am reminded of the philosopher Michael Raposa's intriguing comment that boredom is 'at bottom a semiotic problem, arising from a difficulty on the part of the bored person in reading the signs or interpreting the information in any given situation as meaningful or interesting' (1999: 2). Raposa's claim begs a few questions about agency in relation to wider circumstances - feeling economically or emotionally trapped is hardly conducive to nuanced semiotic analysis, for instance - but he makes the useful point that character and complexity of observation can mitigate the deadening effects of an otherwise alienating situation.

Still, there is more to this experience of relative ritual de-alienation than becoming an ethnographer. The semiotic direction of my 'transformation' is more precise, and has a more specific comparative element. My work as an anthropologist of religion has not been on Judaism, ${ }^{6}$ but on forms of Christianity, including Pentecostalism - a form of religious activity that, as a PhD student, I had assumed would take me as far as possible from the stultifying rituals of my youth. Certainly, my initial attraction to charismatic worship was an aesthetic one: I felt an affinity for its sudden shifts in scale, rhythm and spatial orientation, its active transformations of ritual tempo through music, word, movement. In the following, I want to argue that my familiarity with Pentecostalism has encouraged me to 'read' my experiences of Jewish ceremonial life in a new way, though reading is too limited a metaphor to indicate the hermeneutically inflected shifts in embodied temporality involved, and the drift in my current experience from pure boredom toward another state: not quite waiting in a conventional sense, but closer to a kind of attendance - involving physical presence without any specified attitudinal or behavioural commitment. Although my coming to recognition of this state came through a distinctly roundabout semiotic route, I think it is more generally present in many synagogue contexts, especially among the many contemporary Jews in diaspora who are not Orthodox - and certainly not the highly pious and visible Hasidim, ${ }^{7}$ known for their long, dark clothes and hats (for men) and wigs (for women) - but rather highly assimilated, negotiating between identities of 'cultural', 'religious' and 'ethnic' Judaism. As Andrew Buckser has recently noted (2011: 84), the anthropology of Jewry contains many excellent ethnographies of Hasidim, who make up under a tenth of the Jews in 
the US, yet little exists on liberal Reform Jews, even though the latter account for more than one-third of the nation's Jewish population. Meanwhile, those who describe themselves as 'just Jewish' make up a quarter of the population, and yet 'are essentially invisible in the anthropological literature' (2011: 84). This chapter therefore attempts to characterize the semi-ritualized attendance of the distinctly non-pious, not only describing it ethnographically but also considering what theoretical payoff might be derived from acknowledging its existence. Such discussions not only ask about how we think ethnographically and theoretically about the so-called 'margins' of religious cores (cf. Buckser 2011: 84), but will also take us into comparative considerations of temporality, subjectivity and religious discipline.

There is of course a long history of mutual entanglement between evangelical Christianity and Judaism. ${ }^{8}$ The Prosperity-oriented believers whom I study in Sweden (Coleman 2000; in press) consistently incorporate both Israel and the Jews into their End-Time Expectations, creating forms of Christian Zionism whereby 'friendship' with Jewish people is also a form of appropriation - what Kristian Steinberg and Anders Lundberg (2015) see as an instrumentalization of Jewish populations, since the latter's presence in the Holy Land and rebuilding of the Temple are regarded as necessary for the Rapture. In a recent article in the Jerusalem Post, Daniel Estrin (2015) calls the regular evangelical pilgrimages to Israel during the Feast of Tabernacles an 'evangelical bear hug', rather felicitously encapsulating the ambiguity of an action that has the potential to combine affection with obliteration (compare also Dulin 2015). ${ }^{9}$

The goal- and future-oriented dimension to such apocalyticism will become relevant as I compare Jewish and evangelical attitudes toward time and ritual (cf. O'Donnell 2015), but my main focus is not on consciously orchestrated links between Christian Zionist and Jewish spaces. Rather, my concern is with how ethnographic experience of Pentecostal cultivation of sincerity, ritual engagement and subjectivity has proved key to my altered stance toward what I previously considered a pointless form of lingering within Jewish ritual contexts..$^{10}$ This juxtaposition has thrown into high semiotic, hermeneutic and phenomenological relief certain dimensions of what I previously took to be merely an imposition of smothering, stultifying, ritual time - of waiting as unpleasant 'weighting. While Elisabeth Goodstein (2005) has referred to boredom in the context of modernity as 'experience without qualities', it is precisely the unearthing of certain qualities that highlight in relating to experience I previously found merely alienating. I argue that such traits emerge from perceiving the time of 'attendance' not as modernist clock-time, nor as pre-modern event time, but as a form of non-event 
time. I do not therefore describe a kind of 'I was there' form of attendance, where one marks presence at a historical event, such as a coronation. Nor, do I mean to use this phrase in a pejorative sense, as in the phrase, 'Well, that was a non-event.' Instead, my perception resonates with what Inger Sjørslev (2013: 95) sees as the problematic facing the fieldworker who seeks entrance into the 'aesthetics of social rhythm' of her informants, hoping thereby to become engaged in a 'joint choreography of social interaction' that can shed light on the field even when 'nothing' appears to be happening. As Craig Jeffrey points out (2008), waiting is both a common human activity and integral to the ethnographic enterprise.

In the context of this book, I am exploring a form of mundane attendance included within, rather than excluded from, ritual temporality, but one whose mundanity does not derive its primary identity through contrast with, and de facto definition of, sacrality. Nor is this a form of waiting pitched between doubt and hope, in other words between intensities of feeling oriented toward particular convictions or goals. Rather, it refers to a form of presence that is difficult to grasp or describe ethnographically, and one that might seem to exist at the margins of ritual action but says quite as much about the character of behaviour within a synagogue hall as any sermon or devoutly delivered prayer. In certain respects, it approximates the 'unfocused presence' that Sjørslev (2013) asserts is important for the ethnographer who is 'hanging out', although in the context of fieldwork such lack of focus itself is oriented toward an ultimate, definable ethnographic purpose, that of gaining data, whereas for the attendance that I describe its very lack of a single motive is an important part of its raison d'être.

In the following, I discuss interdisciplinary writings on boredom and waiting, before moving on to describe Pentecostal experiences of ritual as I have observed them in the field, exploring in particular what I see as the abhorrence of boredom that is produced in such contexts. Both of these analytical moves help me to frame my subsequent recharacterization of Jewish ritual as understood by myself and others, and in particular my interest in variations on a theme of ritualizing non-eventfulness.

\section{On boredom and waiting}

Literature on boredom takes me along some of the theoretical trajectory that I want to pursue, given that it encourages reflection on varieties of alienation from present circumstances. An important distinction is between what Samuli 
Schielke (2008: 256) sees as 'the situational boredom everyone experiences sometimes, for instance waiting for a bus' and 'a more existential state of lack of future and hope, intimately coupled with frustration, and often close to despair'. Schielke's differentiation parallels Haskell Bernstein's much earlier (1975: 513) contrast of 'boredom as responsive feeling' with 'boredom as malaise'. In other words, a situational or responsive state is a product of the person's experience of specific, time-bound circumstances, as opposed to a much more chronic and possibly psychologically and/or structurally induced condition.

Both of these modes imply the cultural variability of boredom. Indeed, as Barbara Dalle Pezze and Carlo Salzani put it, 'boredom ... has a history' (2009: 12), and has varied over time and space. ${ }^{11}$ Acedia has long been recognized in Christian circles, implying 'loss of spiritual connection to the divine' (Goodstein 2005: 4), spiritual sluggishness, dullness in prayer, and a lacklustre attitude toward rituals of devotion (Raposa 1999: 2); however, the term is more associated with sin than is common in current parlance, and in medieval Europe seems to have been confined to monks and higher echelons in society, as opposed to the more democratic forms evident today (Dalle Pezze and Salzani 2009: 8). Similarly, taedium vitae - disgust with life (Toohey 2011:15) - is associated with a cultural and social satedness only possible for aristocracy and the rich. ${ }^{12}$

Goodstein sees boredom haunting the contemporary West in specific ways. ${ }^{13}$ Its contemporary links between the static and the unproductive emerge out of 'a modern conception of history as progress' (2005: 5), where individual human life is also ideally placed on a trajectory of chronic movement and improvement. In this sense, boredom emerges as a side-effect of the capacity to conceptualize alternative and better prospects, so that it 'marks the discrepancy between the actual and the imagined - the subjective cost of the limits to realizing the Enlightenment vision of infinite rational progress' (2005: 124). Boredom is thus associated with a surfeit of unwanted, static time, given modern linkages between evoking desire and the ongoing formation of identity (2005: 35). It may appear to slow time-space, disrupting habit and contending ambiguously with forms of hope (Anderson 2004). As Henri Lefebvre famously puts it in his 'Notes on the New Town', part of his Modernity: 'Boredom is pregnant with desires, frustrated frenzies, unrealized possibilities. A magnificent life is waiting just around the corner, and far, far away' (1960: 124). ${ }^{14}$ A sense of thwarted subjectivity emergent from the awareness that things could be otherwise - connects modern boredom with histories of Romantic self-realization, described by Bernstein as 'the expression of the individual's incapacity to fully experience his own feelings with directness and intensity' (1975: 517). Repetition per se need not produce 
boredom: it is more a matter of monotony associated with lack of agency and advancement (see also Hage 2009), and divorced from the comforts of nostalgia. Contemporary ethnography finds similar frustration in non-Western contexts as well, such as Schielke's (2008: 252) tracing of the characteristics of boredom and despair in rural Egypt, where monotony is converted into boredom precisely through the presence of powerful yet unfulfilled aspirations for a better life. Daniel Mains (2007) documents the enervating experiences of young men in urban Ethiopia who are embedded in ideologies of progress through their education, but whose unemployment produces a sense of stasis for which the only solution appears to be migration. Similarly, in Craig Jeffrey's (2010) analysis of 'timepass' among lower middle-class college students in North India, surplus time is perceived as otiose in part because of the cultivated education and crushed ambition of the people involved.

These depictions of modern boredom show how it is potentially implicated within, but not identical to, experiences of waiting. Boredom is a state, while waiting is an activity, even though the former may be caused by the latter. Waiting may conceivably be the opposite of boring (Hage 2009: 12), replete with fulfilling activities and oriented toward a firm date for moving on to the next stage of one's life trajectory, such as travel before going to university or starting a new job; it may also involve a temporary respite from the hustle of the everyday, such as resting on a station platform for a few minutes before a train arrives. However, even these kinds of waiting run the risk of shading into frustration and boredom: aimless or disappointing journeying comes to feel like procrastination, as 'wait' becomes 'waste' in terms of modern conceptions of temporal utility, or the train is delayed so that calming liminality turns into restless anxiety, out of sync with societal wider rhythms (Schweizer 2005: 781). The character of one's object can play an important role in determining the experience of waiting, as suggested by Vincent Crapanzano's (1986) contrast of 'instrumental waiting' for a specific object with 'existential waiting' for abstract aims such as world peace. Furthermore, as Crapanzano points out, the object anticipated may not be desired but dreaded; Jeffrey agrees (2008: 955) that an emotion such as panic is very different to that of heightened suspense. Both waiting and associated boredom appear, then, to present a wide palette of shades of emotion, anticipation and duration. Even though 'attendance' as I think of it displays significant differences from modern boredom, literature on the latter helps to delimit some of the ways to categorize such (in-)action. Attendance, hedged around by ritual, corresponds more with 'situational' and 'responsive' orientations than an 'existential' one. It is also a democratic rather than an elite orientation, available to all Jews who find 
themselves, for whatever reason, participating in a service. Things become more complex in relation to subjectivities of self-improvement and progress: part of the distinctiveness of this ritual mode is that it generally lacks a clear object. Naturally, people go to synagogues for a variety of reasons, ranging from piety, to sociability, to doing what is necessary to 'qualify' for a Bar or Bat Mitzvah. But there are other dimensions to their attendance, and my argument is that the heterogeneity and diffuseness of these dimensions tells us something about the kind of subjectivity available to many contemporary Jews. To explain further what I mean, I now turn to the opposite of attendance, and a state much more obviously 'modern' and even 'religious', as we more usually understand these terms: in other words, to certain Protestant forms of engaged presence.

\section{Being there: Protestant presence and the banishment of boredom}

Because I have spent most of my ritual life not in synagogues but in evangelical and Pentecostal meeting houses, I am used to believers reading not from synagogue-supplied siddurs, but from personalized Bibles whose heavy patterns of wear signify their regular use at home as well as in church. I am used to preachers not so much parroting carefully prepared notes as striding up and down the stage, pleading and/or praying for inspiration to come directly from God. And above all I am used to enthusiastic audience participation: jumping, crying, falling, even running.

There is admittedly one obvious parallel between such rituals and those I have experienced in synagogues: the considerable amount of repetition that is involved, although admittedly the type of repetition is different. Much Jewish ceremony consists of saying Hebrew prayers one has intoned many times before (and often memorized, although not necessarily understood). Pentecostal worship, especially in Prosperity contexts, tends to invoke repetition as a kind of accumulation of divine power, especially given its language ideology, which assumes the performative effect of words (Coleman 2000). To sing the simple verses of a song again and again (perhaps speeding up with each iteration) is not just to lull oneself into tonal and temporal communion with others. It also builds up the positively charged presence of divinely inspired words uttered by people who have become empowered speakers as a result of their born-again identity. So these words matter in particular ways. They not only signify the spiritual power as opposed to mere technical competence of the speaker but also have 
effects on the self and others. They reach into the moment: to speak them both is, and creates, an event.

In such contexts, to openly speak of or express boredom is taboo: it would be the outward expression of a moral condition akin to a Pentecostal version of acedia, and for committed Prosperity Christians would imply a 'negative confession' with potential ill-effects in the physical world. Of course Pentecostal enthusiasm has a complex history, some of which reaches back into broadly Protestant roots. Webb Keane (2006) captures much of what is at stake in his use of the phrase 'anxious transcendence' to describe reformed Christians' concerns to surpass the bounded materiality, mediation and externality of verbal forms in order to create possibilities for unrestricted, spontaneous, sincere, relationships to language and the divine, within and beyond worship contexts. Sincerity for Keane posits speakers as self-possessed and responsible for words that also echo the inner state of the person (Keane 2002: 74). To achieve this state cannot be taken for granted, and Keane draws on Lionel Trilling's claim that sincerity in its fullest form demands 'arduous effort' (Trilling 1972: 6). Trilling provides an intellectual thread that helps Keane broaden his perspective from an examination of Dutch Calvinist missionaries toward wider considerations of what makes the modern. While for Goodstein boredom 'haunts' modernity in its emergence in cases of thwarted progress, for Keane (2006: 310) the transcendence offered by sincerity and spontaneity 'haunts' modernity in its positing of 'three unrealizable desires: for a self freed of its body, for meanings freed of semiotic mediation, and for agency freed of the press of other people'.

Prosperity contexts involve much overt semiotic mediation in the form of repeated words, to be sure, but believers nonetheless regard themselves as deploying language spontaneously, freely, even as they join in chorus after chorus of a song: thus singing may drift between conventional line and speaking in tongues, expressing spiritual inspiration and lending a spontaneous gloss to iteration. Furthermore, while such collective worship involves elements of play and humour it is also intended to be hard, focused work, the exercise of a Pentecostal Ethic that prompts each individual to cultivate an engaged self as devoted listener but also speaker of powerful religious language. Certain ritual techniques may be used to create felicitous temporal conditions for focused engagement. For instance I remember occasions when Ulf Ekman, the former head pastor of the Word of Life ministry in Sweden (Coleman 2000), would tell his congregations never to look at their watches during the service, the point being that they might be present for 30 minutes or 3 hours, depending on the workings of the Spirit. Worship as anticipation of the advent of divine presence 
should not be compromised by the limitations of clock time. Ekman, in common with many Pentecostalist preachers, required the doors of the worship hall to be closed during sermons, signalling that preaching was an event bounded by intense forms of attention. Another preacher in Sweden frequently called on his congregation to reflect closely on what was happening amongst them ' just $n u$ ' 'right now' - entailing a sharpening of everyone's spiritual antennae in order to appreciate the significance of the ritual moment (Coleman 2011). Although he is talking about a very different form of evangelicalism, Matthew Engelke's (2007: 2) description of Friday Apostolics in Zimbabwe resonates with this discussion when he refers to the Apostolic search for an immediate relationship with God, 'live and direct' - creating a context where evoking the presence of God requires the believer's discipline to learn how to 'be' fully in the present.

Whether or not boredom emerges in Prosperity contexts, it should not come to public recognition - nor to personal consciousness - if at all possible. We see how such activity performs the hard labour of trying to exorcize Goodstein's haunted qualities of modern boredom while retaining Keane's anxiety over transcendence. Adapting to fieldwork at the Word of Life involved my striving to listen to sermons of an hour or more, often made up of themes and phrases I had heard many times before, while imagining that I was hearing them for the first time. As I have written elsewhere (Coleman 2000), on one occasion I was so fed up by one American preacher uttering what seemed to me to be hackneyed sentiments that I felt an urgent, almost physical need to walk out of the hall, only to find myself wondering subsequently whether a Word of Life supporter would have interpreted my exit as a sign that spiritually charged language was finally penetrating my spiritual consciousness. In any case, part of the seeming paradox of Pentecostal worship is that it suggests the believer gains self-empowerment and agency through surrender to God, so that any feelings of resistance to submission (such as feeling thoroughly bored) can then be interpreted as the 'fleshly' part of the person opposing, or attempting to take dominion over, the true, spiritual self.

The work being done not only involves a disciplining of the self through ritual focus and tempo(rality), however. Such revivalism is also pitched toward much broader, more ambitious aims, according to which enthusiastic ritual combines with expansive mission in creating a sense of evangelical urgency and eschatological expectancy before the prospect and progress of the imminent 'last days'. What I have called 'historiopraxy' (Coleman 2011) refers to the Word of Life sense of cultivating a proleptic sense of making a present that, from the perspective of the future, will be recognized to have been a radical 
transformation: in other words, not sliding back into mere oscillations between revival and retrenchment. Such praxis involves a construction of history as a stream of novel events, freed from the burdensome weight of the past (cf. Lambek 2002).

In summary, Pentecostal engagement in worship consists ideally of: a focus on the present in order to produce the future; a disciplined creation of presence of both the divine and of receptivity to the divine; a consequent abhorrence of boredom as moral state of disengagement; a striving for common action alongside an individualization of spiritual responsibility. If all of these elements valorize the ritual production of impatience, they also suggest that ritual is inherently connected with waiting as imminent expectation plus personal, if spiritually derived agency, making all who participate work toward a Pentecostal vision of progress. It is now time, then, to ask how all of these elements set up an interpretative, hermeneutic frame through which to move away from Pentecostal 'presence' toward Jewish 'attendance'.

\section{Being present, but in a different way}

In a subtle set of essays, Thinking in Jewish (1996), Jonathan Boyarin explores processes of Jewish self-making through such elements as history, embodiment and language. In his first chapter, he deploys the metaphor of 'Waiting for a Jew' to refer to two aspects of Jewish life: one is the reliance of small synagogues like Boyarin's on a core group of people who regularly make up a minyan, a quorum of ten religiously responsible people whose presence is necessary before public worship can begin; the other aspect is more diffuse, referring to Boyarin's long, halting journey from growing up in a largely non-practising family toward becoming a practitioner and scholar of Judaism.

It is clear that Boyarin belongs to a recognizably American cohort of strivers and workers, and in this sense his experience 'of time and selfhood' parallels that of many aspirant and already middle-class Protestants. On the other hand the forms of ritual waiting and worship he describes seem a world away from the restless, linear orientation of evangelical Christianity: Boyarin's gradual accumulation of his Jewish identity lacks a dramatic conversion narrative, and is more about emergent participation than excited anticipation as he comes to terms with a specific community - Eighth Street Shul - in a particular place - New York.

Boyarin's second chapter, 'Self-Exposure as Theory: The Double Mark of the Jew, continues to examine the chronic formation of religious subjectivity - or 
'the relation between formations of chronology and those of selfhood' (1996: 38). Admitting that this chapter has an androcentric bias, Boyarin analyses circumcision and the habitual wearing of a yarmulke (skull-cap). Both are indices of male Jewish belonging (and in Butlerian terms [1990], male-making), even though one involves a form of physical removal (visible only in private) and the other a form of material addition and adornment (publicly displayed). Although Boyarin complicates his oppositions, he notes: 'The central metaphor for our analysis is the "double sign" of Jewish male ethnic identity: one inscribed on our genitals before we were ever able to exercise will, the other placed on our heads in a free-willed if ambivalent act of self-identification with ethnicity that we carry with us into such social spaces as anthropology conventions' (1996: 34).

Experience of these 'marks' says much about temporality, self-cultivation and subjectivity, and ultimately the character of ritual attendance. Boyarin (1996: 49) describes circumcision as not remembered by the individual and yet invoking a sense of inheritance, a wider history and genealogy, so that 'the incorporation, both literal and figurative, of Jewishness as an aspect of the self implies an experience of time that is panchronic and empathetically expanded' (1996: 39). Indeed, Jewish senses of past temporality tend to become richly entangled with the development of personhood, and not just that of males. Melanie Fogell's discussion of 'new Jewish identities', tellingly titled Ambiguous Selves, notes that 'The expression "never forget" is a familiar admonition for Jews' (2006: 171). The apparent impossibility of certain forms of amnesia emerges from what she sees as Judaism's chronic retelling of history, as famously enacted in the Passover service, when recounting the story of the Exodus of Egypt becomes rooted in domestic sociability combined with instruction of the young. It is important to remember that Passover, like the Bar or Bat Mitzvah service, is celebrated by many Jews who regard themselves, without any embarrassment, as being agnostic or atheist. Furthermore, the narratives being recalled, such as that of the Exodus, are often about patience rather than impatience in relation to time, involving the need to acknowledge the continued salience and presence of the (often traumatic) past rather than proclaiming any urgent 'historio-praxic' obligation to (re-)form the future. There is a telling detail in the Passover service that illustrates this point bodily, called the 'leaning. The idea is that the leader of the service and perhaps some others should explicitly recline to one side, suggestive of a person of leisure who is now free, as opposed to enduring the slavery that was the fate of Jews in ancient Egypt. This ritual performance of a conspicuous lack of effort embodies both an acknowledgement and a ritual harnessing of history, enacted through an idiom of ease and lack of tension. ${ }^{15}$ The Holocaust, 
in turn, has become a paradigmatic emblem of more recent historical trauma, and it is telling that many synagogues ask young people undergoing Bar and Bat Mitzvahs not only to celebrate their own coming to adulthood, but also to select, acknowledge and publicly narrate the story of a young person who was killed during the Holocaust and thus prevented from reaching full Jewish personhood. Various forms of temporality - as patience, world history, ancestorhood and genealogy - are thus brought together as part of this self- and other-oriented cultivation of subjectivity. ${ }^{16}$

Notice the complex intersections and tensions in these examples between identity as taken-for-granted inheritance and as active cultivation, between obligation and autonomy (Horowitz 2011: 88) in the making of Jewish subjectivity - even or especially among the non-religious. Bethanie Horowitz (Horowitz 2011: 82) notes that a key question for twenty-first-century Jews is where their Jewishness figures in relation to other aspects of the self, and her point leads us back to Jonathan Boyarin's consideration of the modalities of becoming Jewish whilst also engaging in the professional striving and linear orientation that resonate with a Protestant Ethic. For Boyarin, ritual engagement with the past and with genealogy is significant in forming the inevitable double consciousness of middle-class Jews. The incorporation of such Jewish temporalities and relationalities contrasts with the figure of the selfmade person - almost by definition a person without history, and one for whom 'the word "success" has lost its connotation of coming after, inheriting, taking the place of' (1996: 38). Boyarin suggests that this American ideal is indeed closely linked to a Christian and particularly a Protestant notion of individual salvation - one involving a 'chronology ... coterminous and contingent with a sequential and progressive individual biography' (1996: 38). His contrast is starkly drawn, but note how his figure of the self-made person, erasing ties with the past in order to achieve freedom and progress, resonates not only with Keane's and Goodstein's discussions of how modernity attempts to exorcize its ghosts, but also with my description of Pentecostalists as ritual cultivators of a future unfettered by the past.

Wearing a yarmulke outside of a synagogue context - the second of Boyarin's marks of the male Jewish person - is not only voluntary (local social pressures aside), but also a much rarer experience among Jewish males than circumcision, and Boyarin notes that the 'gap between the two marks of identity ... becomes in some ways more acute in a period when a large plurality of Jewish males are circumcised and yet do not practice Judaism or identify as religious Jews'(1996:54). We see dramatized here two different kinds of ethical self-making, with different 
temporal implications: the choice, renewed each day, of wearing the yarmulke, versus the physical fact of having been incised. Adopting the yarmulke is an act of chronic, everyday self-disciplining, especially given the attention and even opprobrium it can attract from others, as well as the fact that its wearer is expected to abide by other standards of behaviour associated with halakha (Jewish law) such as making loaded decisions as to whether a given restaurant or friend's home is sufficiently kosher to fit personal standards. To some degree, the experience of wearing the yarmulke comes close to the more tension-filled, everyday, reformist pieties of Protestants or indeed devout Muslims, but in the context of this chapter it is the temporalities associated with circumcision that are more intriguing. Circumcision is the more irreversible but also the more widely diffused act, expressive of a sense of Jewish identity as always already part of the person, before any personal choice could be exercised; it is emblematic of the idea that the Jewish body (whether male or female) is inherently set apart in a way that is irreversible, no matter how lax the daily behaviour of the person. Indeed, it is worth noting that the ceremonial marking of the Bar and Bat Mitzvah is not strictly necessary for the Jewish person to be qualified to assume their adult ritual and moral responsibilities. It does not make the person qualified in performative terms: it acknowledges that they are so.

We have now come a long way from Protestant productions of ritual impatience, or missionary orientations to remaking the world. On balance, recognition of the continued salience of the past takes liturgical precedence over remaking the future. The ritual deployment of language remains important and multifaceted, but repetition of ancient Hebrew words is more of an index of competence than an accumulation of divine power, as well as a bringing to life of holy script through public reading (e.g. Engelke 2007: 19). The relationship of those words to personal subjectivity is also rather different to the Pentecostal example: while the intoning of Hebrew prayer in public involves bodily disciplining, it is not inherently linked to valorizations of spontaneity. So we are ready to come back to Jewish ritual, to look more closely at its temporalities, to see how it constructs forms of 'attendance' among its participants, whether or not they are feeling bored.

Andrew Buckser's book After the Rescue (2003) examines Jewish identity and community in contemporary Denmark by focusing on a congregation based in Copenhagen. The very title of the book brings temporality into the analysis, as the community he describes is one thriving after the traumas of the Second World War. At the same time, it is a community that has taken advantage of a relative lack of anti-Semitism to flourish and fragment, and indeed to assimilate 
into wider Danish society, so that Jewish identity is negotiated alongside a strong sense of secular (albeit Christian-inflected) citizenship. Buckser thus describes a diasporic community that is relatively similar to the one in Toronto that I referred to earlier, with constant questions raised over how reproduction of Judaism can occur. An interesting strategy of the Danish population is to seek ritual safety in numbers, in the sense that it sees itself as a 'unity' congregation, bringing together Jews of very different persuasions and levels of commitment, and thus combines Orthodox ritual forms with, for instance, the recognition of mixed-marriages (2003: 64-65).

Buckser's chapter on ritual is most relevant. In certain respects, he describes an experience familiar from contemporary churches, involving services that are carefully choreographed, with most of the action focused on the bimah, so that the process of the ritual thus involves an unfolding social and political drama, as the rabbi calls different members of the congregation to take part in different tasks' (2003: 70). His experience takes a different turn, however, when during a service he happens to ask his neighbour what is meant by a Hebrew inscription on a wall, and discovers that neither his immediate interlocutor, nor those around him, have any idea how to translate the words. Indeed, he finds that most Jews in the congregation speak little or no Hebrew, so that the content of the service is opaque to them unless they follow the translation in their siddurs. There is, however, a significant ambiguity here contained in the word 'speak': many members can indeed utter Hebrew in the sense that they can intone prayers and some texts, but that does not imply that they have any idea how to translate the words. Buckser describes an occasion during Yom Kippur, the Day of Atonement service, when during a particularly well-known prayer, the Avinu Malkeinu, ${ }^{17}$ the effect becomes electric as thousands of voices come together: 'I saw a number of men I had interviewed in secular settings, men who had declared a complete disinterest in religion and admitted plainly that they knew little or nothing of Jewish liturgy, now decked out proudly in ritual garments and singing along loudly with the congregation' (2003: 84). It is familiarity with the prayer that enables such temporary collective participation and repetition. This event has distant echoes, in oral form, of the evangelical Bible, well worn through use; and yet, in terms of Protestant frames of 'sincerity' we might ask how words can faithfully echo 'interiority' if the speaker has no idea what they are saying. In fact, this is clearly the wrong lens through which to assess what is going on. Such singing is a point of brief ritual articulation among those present, not an expression of semantic communion. While it demonstrates the possibility of mutually coordinated choreography, there is no obligation for 
such coordination to be consistently maintained throughout a service. People come and go at will, and much debate occurs among family and friends as to when to leave. Buckser recounts an occasion when he is invited to dinner with a family who decide to go home early on Yom Kippur, thus missing the blowing of the shofar ${ }^{18}$ that he had assumed would be the climax of the entire service (2003: 85).

When Buckser asks informants about this apparently haphazard dimension of services, he notes that they tend to laugh in recognition, but do not express disapproval. What is in ritual play is not a disciplining of congregants into shared displays of belief but rather making accessible 'a common language through which Jews can speak to themselves and each other about what it means to be Jewish' (2003: 66). Arguably, such a language is effective precisely because it lacks semantic content, 'meaning' in a strict Protestant sense (Engelke and Tomlinson 2007), leaving space for extensive sociality. ${ }^{19}$ Nonetheless (Engelke and Tomlinson 2007: 88), one ritual does seem to have relatively uniform support: that of circumcision. Life-cycles generally involve the most intense forms of conflict among different factions of the community, but circumcision brings ambiguities of identity most sharply into relief. Fuzziness of engagement is counteracted by the need to make a stark decision: to circumcise or not to circumcise ${ }^{20}$ As in Boyarin's analysis, such a ritual act - essentially irreversible is also the one most likely to be adopted by even the most liberal and non-believing Jews. Circumcision thus becomes about inscribing a form of temporality on to the body: the always already. It may even be seen as an extreme example of Douglas's (1970) grid-group diagnosis of social formation and ideology: strong group (collective boundary) is accompanied by weak grid (internal regulation). Once membership to the collective is publicly acknowledged, further action becomes optional.

Buckser convincingly depicts congregants milling around a 'common reservoir of symbols' (1970: 66). I suggest that in addition he is describing a fine example of what I call 'attendance'. Attendance should not be confused with attention, since the focus of activities during services can be varied to say the least. ${ }^{21}$ Nor is the congregant expected always to coordinate their actions with all others in the room. I suggest, in fact, that it is the very production of ritual inattention that is most notable here. By deploying this term, I mean something different to Goffman's (1972) 'civil inattention', which he saw as the means through which strangers in close proximity achieve neutral forms of interaction. While I invoke Goffman's sense of a public gathered largely harmoniously in a dense space, my point is that the general lack of a strong obligation to focus 
on centralized worship allows the possibility for numerous other, smaller scale, forms and frames of sociality to develop, or simply for a congregant to be physically present but mentally preoccupied with something else entirely.

Thus the ritual 'problem of presence' for these participants revolves not around the troubling debates over incarnation and materiality that vexed Engelke's Friday Apostolics, but in relation to a different kind of immanence: the achievement of human gathering oriented around an identity that is already 'given' and yet being rearticulated in public. As the title of Buckser's book - After the Rescue - also implies, this is an immanent presence haunted by a powerful form of human absence, that of Jews who have suffered threats or extinction in historical events that iconically include but extend far beyond the Holocaust. ${ }^{22}$ The particular quality of attendance created in such worship is brought into semiotic relief by contrasting it with the chronic, anxious work on the self and wider world evident in certain Protestant ritual forms. I am not suggesting that congregants consciously define themselves in opposition to Christian ritual, although a few may. Rather, I am portraying the enactment of an identity that is in part, and perhaps paradoxically - asserting its very lack of a need constantly to disciplined and re-created by ritual forms. Belonging has already been achieved; ritual becomes less about pitching oneself toward an eschatological future and more an expression of the fact that the workings of history have not eradicated one's presence. Indeed, it is one's continued existence as a Jew, no matter how non-practising, that seems significant for many modern, liberal congregants in Europe and North America.

If I were given the opportunity to re-encounter my 13-year-old self, I might point out that boredom can sometimes be a luxury, signalling an ability to remove oneself performatively from having to engage with tension-filled action. Under certain circumstances there is much to be said for keeping ritual expectations low, in contrast to the kind of orientation that assumes that spiritual progress toward a desired end is not only a necessity, but also a responsibility - a 'weight' as well as a wait in relation to the future. The temporalities and agencies of Jewish ritual often establish a very different attitude toward history. Hence the doubling up of the Bar/Bat Mitzvah candidates, living and dead, in order to exorcise the horrors and extinctions of the recent past; hence the ostentatious leaning during Passover, cocking a ceremonial snook toward an enforced history of slavery and displacement; hence the easy moving in and out of the temporalities of potentially exact(ing) ritual worship. After all, Jewish time can never truly be tamed: it always has the capacity to harm. And so 'attendance' has qualities of restoration but also of insouciance. Certainly, having the hard shell 
of ritual practice performed in one's presence provides a means of associating oneself with a common liturgical language; but it does not involve a procrustean alignment with such practice, in ideological, temporal or performative terms.

\section{Comparisons and conclusions}

In his analysis of features of mutual articulation among ritual symbols, song and dance among the Merina of Madagascar, Maurice Bloch famously comments that 'you cannot argue with a song' (1974: 70) on the grounds that ritual does not rely on forms of communication that have explanatory, propositional force. Rather, the effectiveness of authoritative ritual lies in its semantic rigidity and extension beyond ordinary logic. The types of semantic articulation characteristic of formalized speech and ritual are 'arthritic' (1974: 64), contrasting with more flexible and pointed conversations that constitute the language of mundane discourse. However, my description of Jewish rites presents occasions where arthritic and non-arthritic forms of communication are closely juxtaposed: if they are not mutually articulated per se, they coexist as symbiotic semiotic practices. Focus on, and participation in, formal ritual comes and goes, as a given participant may move swiftly between joining in a Hebrew song and then turning round to instigate a lively dialogue with friends or family.

Part of the force of Bloch's argument centres on the idea that ritual formalization creates authority by removing what is said from any particular time. In the cases I describe, the temporal orientations of formal ritual and informal conversation are different but largely complementary. 'Attendance' involves being in proximity to 'arthritic' ritual forms, often uttered in an archaic language that recalls the deep history of Judaism; but it does not imply the necessity of being constantly bound by the collective rhythms of such ritual. It may be hard to argue with a song; but one can ignore it. Here, the role of the rabbi is significant as a distinctly limited orchestrator of what goes on: while some Jewish traditions acknowledge the existence of inspired religious figures, most rabbis act as teachers rather than spiritual gurus. They lack the ontologically set-apart status of a Merina elder or a powerful Pentecostal preacher.

Boyarin and Boyarin refer to the anxieties among Jewish Studies faculty members over having their work cast in a comparative framework (1997: ix). It is as if the rhetorical exclusivity of the faith discourages scholarly juxtaposition. Nonetheless, I have suggested the value of interpreting experiences of Jewish ritual through an ethnographic habitus more accustomed to working with 
Pentecostalism. Admittedly, for the most part this exercise has revealed contrasts in ideological approach and ritual stance. However, it also possible to discern limited parallels with other forms of Christian ritual, and I shall mention just two. In her discussion of the fate of the 'middle ground' of religious life in Europe - the large number of people, perhaps 50 per cent, who are neither actively involved in religion nor consciously opposed to it - the British sociologist Grace Davie refers to the significance of 'vicarious religion': in other words, religious activity performed by an active and knowledgeable minority on behalf of a less committed majority (e.g. Davie 2010). Davie's aim is to probe the often implicit but still important connections between lukewarm parishioners and historic churches. Support for such churches comes in the form of general goodwill and even financial support but not regular attendance. Her concept captures something of the attitude I have traced among diasporic, liberal, Jewish populations - the sense that people are content for regular ritual events to take place, even if they do not regard their own presence as strictly necessary on more than an occasional basis. I am not sure, however, that Davie's vicariousness quite captures the Jewish identification with a faith so intimately tied up with twin questions of both reproduction and repeated historical threat. While much religious responsibility in Jewish Toronto and Copenhagen lies with learned ritual specialists, individuals remain responsible for creating families where a Jewish genealogy can continue to exist (and here, a relative futureorientation does make its entrance). Potential tensions between obligation and autonomy, identity commitment and ritual insouciance, are well expressed in the ambiguities of the Bar and Bat Mitzvah: the public marking of the coming to Jewish adulthood of a young person who may, like his or her parents, be atheist. The ambivalences toward such occasions were nicely captured in the remark I heard many years ago, made at the post-Bar Mitzvah celebration of a friend of mine by his grandmother: 'The party is lovely. Why did we need to have the shul ${ }^{23}$ bit?'

Comparisons with non-Protestant forms of Christianity are also instructive. Andreas Bandak and Tom Boylston's (2014) analysis of ritual correctness and orthodoxy among Christian Orthodox populations includes an emphasis on modes of relating to authority that create room for pluralism and heterodoxy within an overarching structure of faith. The 'orthodoxy of Orthodoxy' thus contrasts with the scriptural, language-oriented orientations toward truth and authority often seen in ethnographies of Christian evangelicalism, and depicts an inclusive and encompassing hierarchy that more easily acknowledges the interrelation between divine perfection and fallible humanity. Under such ritual 
circumstances, the chronic cultivation of a pious self seems less significant than the assumption that somebody, somewhere, knows what should be done. I would not describe such attitudes as 'insouciant', and of course they maintain very different attitudes toward both incarnation and temporality to those evident in synagogue life, but they parallel the Jewish attitudes I have described in their open-endedness toward the necessity for individuals relentlessly to seek religious truth.

I do not claim that what I call 'attendance' is the only mode or register evident within Jewish ritual. However, I suggest that, in common with many manifestations of 'waiting', it is easy to overlook as it occupies the interstices between more marked or definitively formed activities. The path I have traced in my argument is away from more easily recognizable forms of ritual alienation and boredom toward a less tangible but perhaps more intriguing state of semidetached and yet deeply social presence. Attendance does not rely on sentiments of thwarted subjectivity, but rather on the cultivation of relative ritual ease, even if at times deeply serious histories are invoked. Such a ritual 'stance', if it can be said to take a single form, draws on the idea of reaching back into a religious past that continues to inform the present. At the same time, it suggests that congregants do not need to wait or work to achieve acceptance: they have always belonged.

\section{Notes}

1 Buckser (2003: 63-64) notes that from the nineteenth century, three main institutional responses emerged among Western synagogues to the issue of adapting Jewish law to modern life. Orthodox Judaism called for fidelity to the law; Reform Judaism focused on adaptation to wider culture; Conservative Judaism struck a balance between the two.

2 Torah refers to the Jewish holy scriptures. Bar Mitzvah means 'son of the commandment' and the Bat Mitzvah, carried out in some synagogues, means 'daughter of the commandment'.

3 Raised platform.

4 Prayer book.

5 Leslie Carlin, also an anthropologist.

6 See Orlove (1997) for reflections on Judaism and carrying out ethnography.

7 Hasidic Judaism emerged as a revival movement in Eastern Europe from the eighteenth century and has since spread throughout Europe, North America and Israel. 
8 Shaul Magid (2015: 4) argues that much of modern Judaism in the West developed under a Christian gaze, and thus sought to distinguish itself from Christian thought, for instance by regarding the incarnation as antithetical to Judaism. Intriguingly, he sees Hasidism as a form of Orthodox Judaism that emerged without such strictures, and thus able to produce a theology more influenced by incarnational thinking.

9 See also, for example, Feldman (2007) on relations between evangelical Christians and Jewish tour guides in Israel.

10 I have discussed the 'multi-sited ethnographer' in Coleman 2006, referring to the analytical stance that emerges as we compare different ethnographic sites throughout our careers.

11 Yasmine Musharbash (2007) links variations of boredom with distinct, local forms of modernity. For her Australian Aboriginal informants, it implies lack of social connectedness - but is never linked to ritual occasions.

12 See also Goodstein (2005: 69) on Durkheim's linking of anomie to modernity.

13 Goodstein (2005: 3) quotes the Oxford English Dictionary as suggesting that boredom was non-existent until the late eighteenth century. The French Ennui and German Langeweile are older.

14 Compare Walter Benjamin's (e.g. 1999) observations (influenced by Simmel) on the character of modern boredom, divorced from the rhythms of more traditional forms of life and prompting the development of forms of phantasmagoria.

15 There is a well-known element of the Passover service that suggests a more proleptic attitude toward history in an attempt to heal spatial displacement: the ritualized cry of 'next year in Jerusalem'. And yet in the context of a widespread diasporic Jewish community that could now return to Israel, but chooses not to, this sentiment has become a matter of tradition more than aspiration for many Jews.

16 Note also how Jewish participants in services are called up to the bimah using their Hebrew name, and mention of the name of their father or mother - language and genealogy combine in locating the person.

17 'Our Father, Our King'.

18 Ram's horn.

19 Thus Buckser states (2003: 101): 'Danish Jews do not share their faith the ways Lutherans share theirs, taking a common position on key issues of theology; they share their faith the way a family shares its past, some embracing it, some rejecting it, each in a different way, yet none capable of understanding him- or herself except in its light.'

20 The importance of circumcision is intriguing in the context of a religion where continuity of faith is passed on through the female line. For wider discussions of the Jewish body, see Diemling and Veltri (2009) and Konner (2009).

21 Indeed, Harold Schweizer (2005: 788) notes that for Bachelard it is the novel and the sudden that engender attention. 
22 The frequently asserted exceptionality of such extinction has become a point of deep political unease and internal conflict among more liberal Jewish populations, given the actions of the contemporary Israeli state.

23 Shul is a Yiddish word, used to describe a synagogue.

\section{References}

Anderson, Ben. 2004. 'Time-Stilled Space-Slowed: How Boredom Matters'. Geoforum 35: 739-754.

Bandak, Andreas and Tom Boylston. 2014. 'The "Orthodoxy" of Orthodoxy: On Moral Imperfection, Correctness, and Deferral in Religious Worlds'. Religion and Society 5: 25-46.

Benjamin, Walter. 1999. The Arcades Project. Edited by Rolf Tiedemann. Translated by Howard Eiland and Kevin McLaughlin. Cambridge: Belknap Press.

Bernstein, Haskell E. 1975. 'Boredom and the Ready-Made Life'. Social Research 42(3): 51-537.

Bloch, Maurice. 1974. 'Symbols, Song, Dance and Features of Articulation. Is Religion an Extreme Form of Traditional Authority?' European Journal of Sociology 15: 54-81.

Boyarin, Daniel and Jonathan Boyarin. 1997. 'Introduction: So What's New?' In Jews and Other Differences: The New Jewish Cultural Studies, edited by Jonathan Boyarin and Daniel Boyarin, vii-xxii. Minneapolis: University of Minnesota Press.

Boyarin, Jonathan. 1996 Thinking in Jewish. Chicago: University of Chicago Press. Cambridge: Harvard University Press.

Buckser, Andrew. 2003. After the Rescue: Jewish Identity and Community in Contemporary Denmark. New York: Palgrave Macmillan.

Buckser, Andrew. 2011. 'On and Off the Margin: The Anthropology of Contemporary Jewry'. Religion and Society 2: 72-89.

Coleman, Simon. 2000. The Globalisation of Charismatic Christianity: Spreading the Gospel of Prosperity. Cambridge: Cambridge University Press.

Coleman, Simon. 2006. 'The Multi-Sited Ethnographer'. In Critical Journeys: The Making of Anthropologists, edited by Maya Unnithan and Geert de Neve, 31-46. Aldershot: Ashgate.

Coleman, Simon. 2011. “Right Now!”: Historiopraxy and the Embodiment of Charismatic Temporalities'. Ethnos 76(4): 426-447.

Coleman, Simon. In press. 'Spiritual Warfare in Pentecostalism: Metaphors and Materialities'. In Companion to Material Religion, edited by Manuel Vasquez and Victoria Machado. Oxford: Wiley-Blackwell.

Crapanzano, Vincent. 1986. Waiting: The Whites of South Africa. New York: Vintage. Dalle Pezze, Barbara and Carlo Salzani. 2009. 'Introduction: The Delicate Monster: Modernity and Boredom'. In Essays on Boredom and Modernity, edited by Barbara Dalle Pezze and Carlo Salzani, 5-33. New York: Rodopi. 
Davie, Grace. 2010. 'Vicarious Religion: A Response'. Journal of Contemporary Religion 25(2): 261-266.

Diemling, Maria and Giuseppe Veltri (eds.). 2009. The Jewish Body: Corporeality, Society, and Identity in the Renaissance and Early Modern Period. Leiden: Brill.

Douglas, Mary. 1970. Natural Symbols. Explorations in Cosmology. London: Cresset Press.

Dulin, John. 2015. 'Reversing Rupture: Evangelicals' Practice of Jewish Rituals and Processes of Protestant Inclusion'. Anthropological Quarterly 88(3): 601-634.

Engelke, Matthew. 2007. A Problem of Presence: Beyond Scripture in an African Church. Berkeley: University of California Press.

Engelke, Matthew and Matthew Tomlinson (eds.). 2007. The Limits of Meaning: Case Studies in the Anthropology of Christianity. Oxford: Berghahn.

Estrin, Daniel. 2015. 'Christian Evangelicals in Jerusalem Show Love for Israel'. Jerusalem Post, 1 October. http://www.businessinsider.com/ap-christianevangelicals-in-jerusalem-show-love-for-israel-2015-10.

Feldman, Jackie. 2007. 'Constructing a Shared Bible Land: Jewish-Israeli Guiding Performances for Protestant Pilgrims'. American Ethnologist 34(2): 349-372.

Fogell, Melanie. 2006. Ambiguous Selves: New Jewish Identities. Calgary: Detselig. Goffman, Erving. 1972. Relations in Public. New York: Penguin.

Goodstein, Elizabeth S. 2005. Experience without Qualities: Boredom and Modernity. Stanford, CA: Stanford University Press.

Hage, Ghassan. 2009. 'Introduction'. In Waiting, edited by Ghassan Hage, 1-17. Melbourne: Melbourne University Press.

Horowitz, Bethanie. 2011. 'Old Casks in New Times: The Reshaping of American Jewish Identity in the 21st Century'. In Ethnicity and Beyond: Theories and Dilemmas of Jewish Group Demarcation, edited by Eli Lederhendler, 79-90. Oxford: Oxford University Press. Jeffrey, Craig. 2008. 'Guest Editorial'. Environment and Planning D: Society and Space 26: 954-958.

Jeffrey, Craig. 2010. 'The Politics of Waiting. The Guardian, 29 May 1-3.

Keane, Webb. 2002. 'Sincerity, "Modernity”, and the Protestants'. Cultural Anthropology 17(1): 65-92.

Keane, Webb. 2006. 'Anxious Transcendence'. In The Anthropology of Christianity, edited by Fenella Cannell, 308-323. Durham, NC, and London: Duke University Press.

Konner, Melvin. 2009. The Jewish Body. New York: Knopf.

Lambek, Michael. 2002. The Weight of the Past: Living with History in Mahajanga, Madagascar. New York: Palgrave Macmillan.

Lefebvre, Henri. 1960. Introduction to Modernity: Twelve Preludes. Translated by John Moore. London: Verso.

Magid, Shaul. 2015. Hasidism Incarnate: Hasidism, Christianity, and the Construction of Modern Judaism. Stanford, CA: Stanford University Press.

Mains, Daniel. 2007. 'Neoliberal Times: Progress, Boredom, and Shame among Young Men in Urban Ethiopia'. American Ethnologist 34(4): 659-673. 
Musharbash, Yasmine. 2007. 'Boredom, Time, Modernity: An Example from Aboriginal Australia.' American Anthropologist 109(2): 307-317.

O'Donnell, Emma. 2015. Remembering the Future: The Experience of Time in Jewish and Christian Liturgy. Collegeville, MN: Liturgical Press.

Orlove, Benjamin. 1997. 'Surfacing: Thoughts on Memory and the Ethnographer's Self'. In Jews and Other Differences: The New Jewish Cultural Studies, edited by Jonathan Boyarin and Daniel Boyarin, 1-29. Minneapolis: University of Minnesota Press.

Raposa, Michael L. 1999. Boredom and the Religious Imagination. Charlottesville: University Press of Virginia.

Schielke, Samuli. 2008. 'Boredom and Despair in Rural Egypt'. Contemporary Islam 2: 251-270.

Schweizer, Harold. 2005. 'On Waiting. University of Toronto Quarterly 74(3): 777-792. Sjørslev, Inger. 2013. 'Boredom, Rhythm, and the Temporality of Ritual: Recurring Fieldwork in the Brazilian Candomblé. Social Analysis 57(1): 95-109.

Steiner, Kristian and Anders Lundberg. 2015. 'Peace and End Time Expectations in Christian Zionism'. Nordic Journal of Religion and Society 28(2): 117-36.

Toohey, Peter. 2011. Boredom: A Lively History. New Haven, CT: Yale University Press. Trilling, Lionel. 1972. Sincerity and Authenticity. Cambridge, MA: Harvard University Press. 